Gut, 1979, 20, 737-742

\title{
Catalytic and regulatory properties of the Triton and trypsin forms of the brush border hydrolases
}

\author{
A. M. UGOLEV, N. M. Mityushova, V. V. Egorova, I. K. Gozite, AND \\ G. G. KOLTUSHKINA
}

From the Laboratory of Physiology of Nutrition, Pavlov Institute of Physiology, Academy of Sciences of the USSR, Leningrad, USSR, and the Institute of Applied Biochemistry, Olaine, Latvian SSR, USSR

SUMmARY Amphipathic enzymes, invertase (EC 3.2.1.26), 8-amylase (EC 3.2.1.3), and alkaline phosphatase (EC 3.1.3.1), were purified from the rat small intestinal mucosa as trypsin and Triton forms, the catalytic and regulatory characteristics of which were compared in rats and in drosophila. Differences in the catalytic properties of the two enzyme forms were demonstrated, which suggested that the hydrophobic part of the enzyme was involved in maintaining optimal conformation of the catalytic part. Many modifiers have been found to influence the Triton rather than the trypsin form of the enzyme. It is therefore suggested that the hydrophobic sub-units of the enzymes might be involved in transmitting information from the cytoplasm into the external surface of the membrane, the cell in this way regulating the activity of surface enzymes. If this is indeed the case, it is suggested that the hydrophobic part performs functions not only of external but also of internal regulation.

The microvillous membranes of the epithelial cells are widely used as a model for the study of the functions of enzymatically active membranes. This is related to the fact that the brush border surface is that site where a close coupling occurs of the processes of membrane hydrolysis and transport of the formed monomers (Ugolev, 1972). One of the important modes of analysis of the enzymatically active membranes may be a separation of enzymes from the enzyme-membrane complexes by various solubilising agents such as detergents and proteases (Eggermont, 1968; Egorova et al., 1975; Louvard et al., 1975; Sigrist et al., 1975; Louvard et al., 1976; Maroux and Louvard, 1976; Pattus et al., 1976; Egorova et al., 1977).

During the past few years it has been shown in our laboratory that some brush border hydrolases are regulatory enzymes and for a number of them allosteric properties have been demonstrated. The results were discussed in detail in our previous works (Ugolev et al., 1975a,b). We later found the same properties not only for the enzymes incorporated into the natural membranes but also those solubilised by a non-polar detergent, Triton X-100. After trypsin or papain solubilisation, however, the enzymes lost their regulatory properties (Ugolev et al.,

Received for publication 13 March 1979
1974, 1975a,b; Egorova et al., 1975). These findings made it possible to suggest that the catalytic and regulatory parts of hydrolases are associated with the enterocyte membranes by two subsequent bonds: one sensitive to the action of proteases and another to that of detergent. The regulatory part was assumed to be located between these two bonds (Ugolev, 1972; Egorova et al., 1975; 1977).

As has recently been demonstrated with purified aminopeptidase and maltase (Louvard et al., 1975; 1976; Maroux and Louvard, 1976), the brush border hydrolases of the enterocytes and nephrocytes consist of two parts, a hydrophilic and a hydrophobic part. The hydrophilic (enzymatically active) part of the enzymes was purified after trypsin treatment of the enzyme preparations (the trypsin form). By the action of detergents the enzyme was completely released, including both the hydrophilic and hydrophobic parts of the enzyme (the detergent or Triton form).

The hydrophilic part is believed at present to perform catalytic functions, whereas the role of the hydrophobic part is far less clearly understood. It is suggested that it plays a part in binding an enzyme molecule with the lipid matrix of the membrane (Pattus et al., 1976)..It is not yet clear, however, whether this is its only function. As mentioned above, earlier data obtained from our laboratory before the 
molecular structure of the microvillous membrane enzymes was recognised suggest that the hydrophobic part may have other functions, including a regulatory one.

The present work is concerned with further study of the functions of the hydrophobic part of enzymes. For this purpose, the catalytic and regulatory properties of the Triton and trypsin forms of carbohydrases ( $\gamma$-amylase and invertase) and alkaline phosphatase were compared. The experiments were carried out on vertebrates (rats) and invertebrates (drosophila) in which the regulatory properties of membrane enzymes were also revealed (Mityushova and Ugolev, 1976). The properties of the Triton form were compared with those of the trypsin form after its complexing with lecithin liposomes. In several instances a comparison was made between the kinetic and regulatory properties of purified enzymes and those of mucosal homogenates and Triton X-100 or protease-solubilised but unpurified enzymes.

\section{Methods}

\section{TISSUE AND ENZYME PREPARATIONS}

The preparation of the mucosal homogenates of the rat small intestine and solubilisation of the enzymes were performed using a routine technique, previously described in detail (Eggermont, 1968; Ugolev et al., 1975b).

Drosophila melanogaster valvae of CS strain were also used in our experiments. Valvae were collected during their release from the medium and rinsed twice in cold Ringer solution. The intestine was extracted through the proximal end of a valve. A segment corresponding to the middle intestine was isolated. For the study of enzymatic activities a homogenate containing 40 intestines in $1 \mathrm{ml}$ Ringer solution was used. All the procedures were performed cold. In some experiments the activity of a quarter of the middle intestine of one valve was investigated.

The Triton and trypsin forms of enzymes were extracted from the intestinal mucosal homogenates of Wistar rats (body weight $180-200 \mathrm{~g}$ ) using a modification of the method of Dahlqvist and Thomson (1963) after preliminary solubilisation by Triton X-100 (0.4\% V/V, Schuchardt, Munich) or trypsin $(\mathrm{mg} / \mathrm{ml}$ of homogenate, Spopha, Czechoslovakia) respectively. In order to obtain purified mucosal preparations the small intestines from 100 animals were used. Figure 1 shows the distribution of intestinal carbohydrases after chromatography using DEAE-cellulose. A complexing of purified carbohydrases with lecithin liposomes $(0.52 \%$ emulsion of this phospholipid was used) was produced by stirring the enzyme-liposome mixture at $4^{\circ}$ for 24 hours (Koltushkina and Ugolev, 1975; Egorova et al., 1977).

\section{ANALYTICAL METHODS}

Invertase activity was determined by an increase in

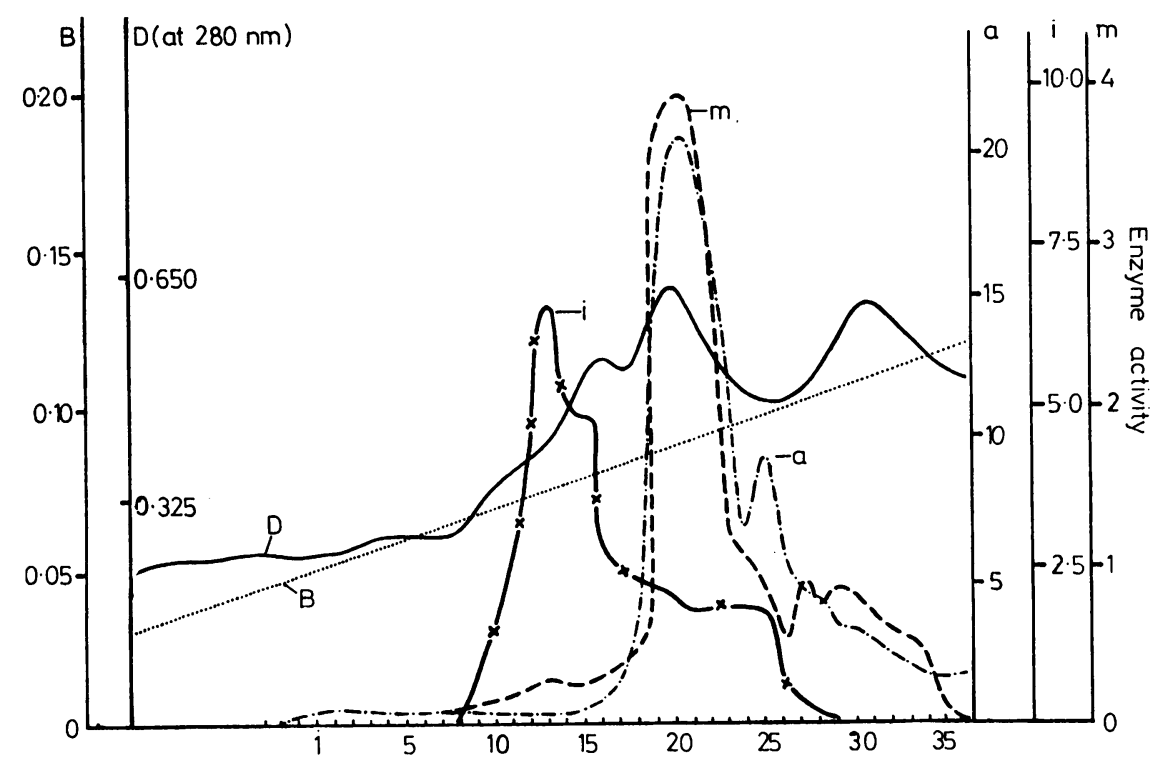

Fig. 1 Distribution of intestinal carbohydrases after chromatography using DEAE-cellulose. $a$ : $\gamma$-amylase; $i$ : invertase; $m$ : maltase; $B$ : concentration gradient of Na-phosphate buffer $(M)$. 
free hexoses using a modification of the method of Nelson (Ugolev and Iezuitova, 1969). Sucrose at a concentration of $1 \cdot 1-23 \cdot 2 \times 10^{-2} \mathrm{M}$ served as substrate. $\gamma$-amylase activity was determined by an increase in glucose by the modified method of Dahlquist (1964). The concentration of soluble starch varied within the limits $1 \cdot 2-40 \cdot 0 \mathrm{~g} / 1$. Alkaline phosphatase activity was defined using sodium p-nitrophenyl phosphate $(0.6 \mathrm{mM})$ as substrate. Tributyrine (6.6 mM) and $\beta$-phenyl- $\alpha$-alanine ( 2 and $20 \mathrm{mM}$ ) were used as the modifiers of alkaline phosphatase activity. The effects of the modifiers were given in percentage of inhibition or activation with respect to the activity measured in the absence of the modifiers and taken as $100 \%$. Protein was determined by measuring the absorbance (at 290 $\mathrm{nm}$ ). Sucrose and starch solutions were prepared on $\mathrm{K}^{+}$phosphate buffer $(\mathrm{pH}$ 7.0) and sodium $p$ nitrophenyl phosphate in Ringer solution. The kinetic characteristics of $\gamma$-amylase and invertase $\left(\mathrm{K}_{\mathrm{m}}\right.$ and $\mathrm{V}$ ) were determined using Lineweaver-Burk plot. The $\mathrm{pH}$ function was investigated in the range of 4.0-9.0. Incubation was carried out at $37^{\circ}$ for rats and at $30^{\circ}$ for drosophila. Various periods of incubation (10 to 30 minutes) were used.

\section{Results}

KINETIC CHARACTERISTICS OF TRITON AND TRYPSIN FORMS OF ENZYMES IN RATS

$K_{m}$ and $V$

Comparison of the kinetic characteristics $\left(\mathrm{K}_{\mathrm{m}}\right.$ and V) of $\gamma$-amylase and invertase purified preparations showed definite distinctions between the Triton and trypsin forms of the enzymes. $\mathrm{V}$ for the Triton form of invertase (Fig. 2) was found to be higher (0.33 \pm $0.02 \mathrm{mM} / \mathrm{min})$ than for the trypsin form $(0.25 \pm 0.02$ $\mathrm{mM} / \mathrm{min}) ; \mathrm{K}_{\mathrm{m}}$ was lower $\left(9 \cdot 1 \pm 0.6 \times 10^{-2} \mathrm{M}\right.$ compared with $\left.12.5 \pm 1.2 \times 10^{-2} \mathrm{M}\right), \mathrm{P}<0.05$. As regards $\gamma$-amylase, $K_{m}$ for the Triton form was found to be lower than for the trypsin form, as in the case of invertase. The enzyme activity of the Triton form at low substrate concentrations, however, was higher and at high concentrations was lower than for the trypsin form of the enzyme. $V$ for the Triton form was also lower than for the trypsin form of the enzyme.

Thus, a conversion of the Triton form of enzymes into the trypsin form-in other words, a separation of the hydrophobic part-leads to changes in the catalytic properties of enzymes. The hydrophobic part appears to play an essential role in a maintenance of optimal conformation of the catalytic (hydrophilic) part of enzymes.

A complexing of the trypsin form of invertase with liposomes-that is, binding of an enzyme with the lipid membrane-was earlier shown (Koltushkina and Ugolev, 1975) to decrease $K_{m}$ and increase V. For $\gamma$-amylase a decrease in $K_{m}$ and insignificant change in $\mathrm{V}$ were observed.

The differences in the kinetic characteristics between the trypsin form of carbohydrases and its complexes with liposomes were similar to those found between the trypsin and Triton forms of enzymes.

\section{pH-function}

Figure 3 shows pH-function for the Triton and trypsin forms of invertase. In both cases the maximum of invertase activity was at $\mathrm{pH} 6 \cdot 5$. However, as can be seen, these curves differ significantly. Thus, the activity for the Triton form at pH 5.0 accounted for $83 \%$, while that for the trypsin form accounted for no more than $27 \%$ of the whole. As a whole, a zone of high activity for the Triton form of the enzyme was wider than for the trypsin form. Our previous studies on the $\mathrm{pH}$-function of invertase, $\gamma$-amylase, and maltase demonstrated that the zone of high activity for the enzyme-liposome complexes
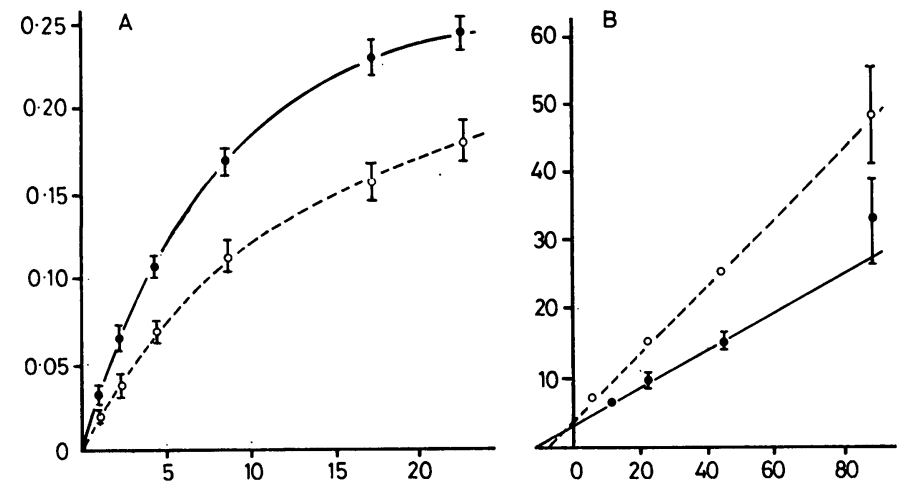

Fig. 2 Determination of $K_{m}$ and $V$ of invertase of the rat small intestine. A: effect of substrate concentration on the rate of hydrolysis; abscissa: concentration of sucrose (in $M$ ); ordinate: the rate of hydrolysis in $\mu M$ per minute. $B$ : LineweaverBurk plot. Abscissa: reciprocal to the concentration of sucrose; ordinate: reciprocal to the rate of hydrolysis. Solid line: the Triton form of the enzyme; dashed line: the trypsin form of the enzyme. 


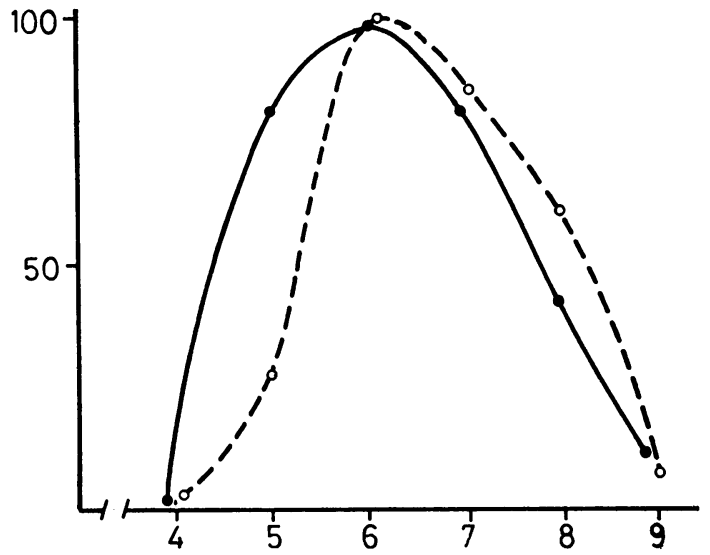

Fig. 3 pH function of invertase of the rat small intestine. Abscissa: $\mathrm{pH}$-value; ordinate: activity (in $\%$ of the maximum taken as $100 \%$ ). Solid line: the Triton form of the enzyme; dashed line: the trypsin form of the enzyme.

was much greater than for the trypsin form of the enzymes. Thus, phospholipid-bounded carbohydrases are more resistant to acid and alkaline denaturation. These findings are well consistent with the results of other investigators which showed that ligands are capable of stabilising and optimising a conformation of the enzyme (Koltushkina and Ugolev, 1975). The hydrophobic part binding the hydrophilic part with the membrane may affect the properties of the hydrophilic part in the same direction as does the membrane.

\section{REGULATORY PROPERTIES OF TRITON AND}

TRYPSIN FORMS OF ENZYMES IN RATS

Figure 4 shows the effects of two modifiers (tributyrine and phenylalanine) on the activity of the Triton and trypsin forms of alkaline phosphatase. The modifiers significantly inhibited the activity of the Triton form of the enzyme $(27 \%$ for tributyrine and $17 \%$ and $37 \%$ for 2 and $20 \mathrm{mM}$ of phenylalanine, respectively, $\mathrm{P}<0.05)$. The activity in control was $1.04 \pm 0.09 \mu \mathrm{M} / \mathrm{min} / \mathrm{mg}$ of protein. Similar inhibition of the alkaline phosphatase activity by modifiers was earlier observed using mucosal homogenates and Triton X-100 solubilised enzyme (Ugolev et al., 1975b). In contrast, the activity of the trypsin form $(1.24 \pm 0.02$ in control) did not change significantly in the presence of tributyrine $(1.26 \pm 0.09)$ and $2 \mathrm{mM}$ of phenylalanine $(1 \cdot 17 \pm 0 \cdot 03)$. Considerable inhibition $(27 \%, P<0.05)$ was observed only in the presence of $20 \mathrm{mM}$ of phenylalanine. However, in this case the level of inhibition was significantly lower when compared with the Triton form of the

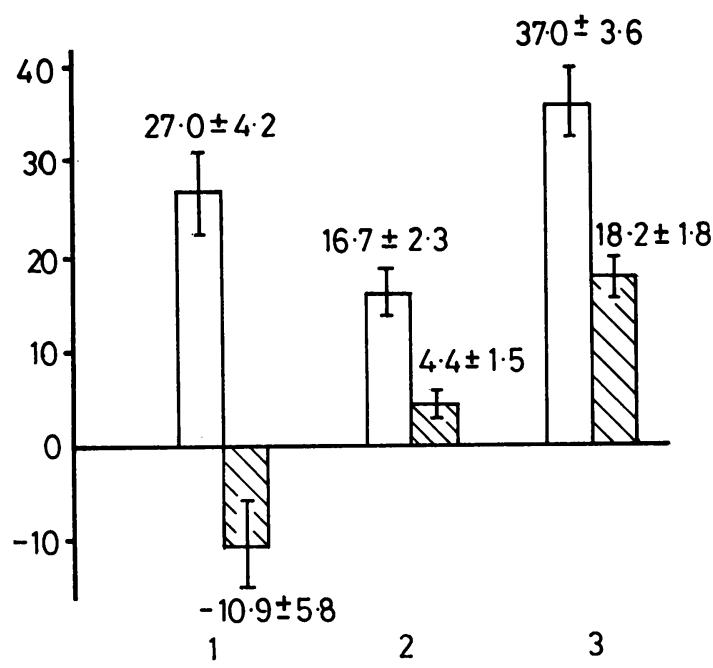

Fig. 4 The effect of tributyrine and phenylalanine on the Triton and trypsin forms of alkaline phosphatase activity of the rat small intestine. White bars: the Triton form; hatched bars: the trypsin form. Vertical line: inhibition (+) (stimulation) (in \%). 1: tributyrine, 2: 2mM phenyalanine, 3: $20 \mathrm{mM}$ phenylalanine.

enzyme. Thus, regulatory properties seem to depend on a mode of solubilisation preceding a purification. Analogous results were obtained from the study of the regulatory properties of $\gamma$-amylase (Fig. 5).

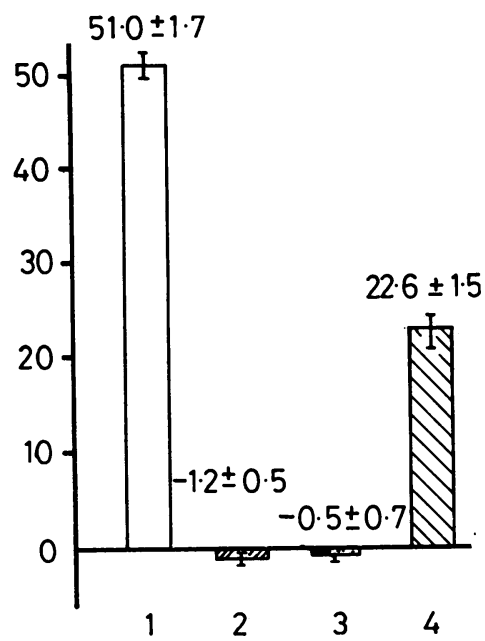

Fig. 5. The effect of tributyrine on the $\gamma$-amylase activity of the rat small intestine. Vertical line: inhibition (in \%). 1: homogenate; 2: solubilisation by trypsin; 3: the trypsin form of the enzyme; 4: solubilisation by Triton $X-100$. 
Thus, inhibition of homogenate $\gamma$-amylase by tributyrine was $50 \%$ and after Triton X-100 solubilisation it reduced insignificantly. However, solubilisation by trypsin without subsequent purification resulted in a loss of sensitivity of $\gamma$-amylase to tributyrine. Modifiers also had no effect on the trypsin forms of $\gamma$-amylase.

Thus, the study of the regulatory properties of the brush border hydrolases demonstrated that modifiers influence both the activity of the membrane-bound enzymes and Triton X-100-solubilised enzymes and that of the Triton form of purified enzymes. Conversely, trypsin or papain-solubilised enzymes and the trypsin form of the enzymes displayed much less sensitivity to the action of modifiers and in some instances lost it completely. Therefore the regulatory properties are peculiar only to the entire enzyme, including the hydrophilic and hydrophobic parts. A separation of the latter results in a deprivation of the enzyme's regulatory properties.

\section{Regulatory properties of alkaline phosphatase of middle intestine in drosophila}

Figure 6 presents data showing the effect of tributyrine on the alkaline phosphatase activity of the middle intestine in drosophila melanogaster. The preparations used were intestinal homogenates, Triton X-100, and trypsin-treated homogenates. As can be seen, the enzyme activity of mucosal homo-

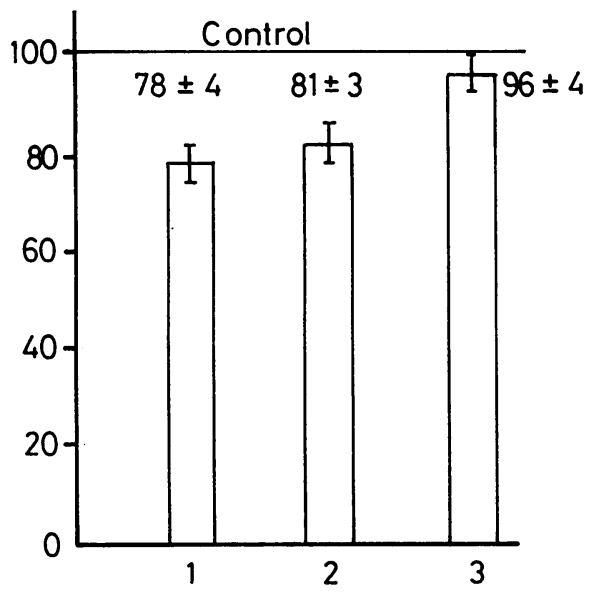

Fig. 6 The effect of tributyrine on the alkaline phosphatase activity of the middle intestine in drosphila. Vertical line: activity in the presence of tributyrine (in \%). The activity of homogenates in the absence of tributyrine (control) is taken as $100 \% .1:$ untreated homogenate; 2 : Triton X-100-treated homogentate; 3: papain-treated homogenate. genates markedly decreased in the presence of tributyrine. The inhibition in this case was $21.0 \%$. After Triton X-100 treatment the activity of the enzyme also reduced under the action of tributyrine $(18.4 \%$ of inhibition). By contrast, when affected by trypsin the alkaline phosphatase activity was not inhibited in the presence of tributyrine.

Thus, during the study of intestinal alkaline phosphatase in drosophila we could observe effects similar to those obtained with the rat intestinal enzymes. In both cases the enzymes of homogenates and those solubilised by Triton X-100 exhibited regulatory properties, while solubilisation by trypsin led to a loss of sensitivity to the action of a modifier.

\section{Discussion}

The results obtained suggest that solubilisation by proteases leads to a separation of the catalytic and regulatory parts of an enzyme molecule, whereas after solubilisation by Triton X-100 its amphipathic structure persists. In other words, catalytic sub-units are solubilised by proteases and the entire enzyme, including regulatory sub-units, is released by detergents. This finding is supported by the circumstance that after papain treatment of the brush border fractions the molecular weights of a number of enzymes are smaller than those after treatment by Triton X-100.

In terms of the hypothesis on the enzyme-transport ensemble (Ugolev, 1972), Maroux and Louvard

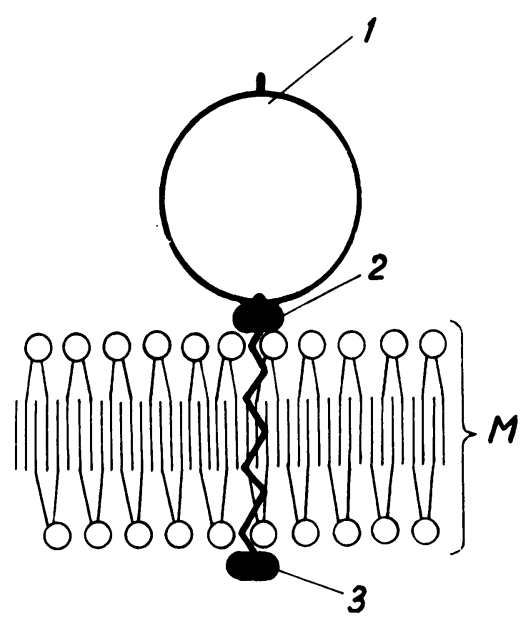

Fig. 7 Model of the amphipathic structure and regulatory properties of the microvillous enzymes. M: membrane; I: the hydrophilic part of an enzyme with the active centre; 2, 3: the hydrophobic part of the enzyme. 
suggested that the hydrophobic parts not only play a role in the binding of hydrolases with the membranes but also participate in transport processes (Louvard et al., 1975). In one of their latest works the authors (Louvard et al., 1976) reported that the hydrophobic sub-unit of the enzyme is, at least partially, located on the internal side of the membrane. Taking into account our data on the regulatory functions of the hydrophobic part of the enzyme, the hydrophobic sub-units might be expected to be involved in a transmission of information from the cytoplasm into the external surface of the membrane. In this way the cell regulates the activity of surface enzymes (Fig. 7). If this be the case, the hydrophobic part may perform functions not only of external but also of internal regulation.

\section{References}

Dahlqvist, A. (1964). Method for assay of intestinal disaccharidases. Annals of Biochemistry, 7, 18-25.

Dahlqvist, A., and Thomson, D. L. (1963). Separation and characterization of two rat-intestinal amylases. Biochemical Journal, 89, 272-277.

Eggermont, E. (1968). The Biochemical Defects in Sucrose Intolerance and in Glucose-Galactose Malabsorption. Thesis: University of Louvain, Belgium.

Egorova, V. V., Koltushkina, G. G., and Ugolev, A. M. (1975). The influence of solubilization on the activity and regulatory properties of some microvillous membrane hydrolases. In All-Union Symposium: Physiological role of Surface Active Substances, Chernovtsy 47 (Abstract).

Egorova, V. V., Koltushkina, G. G., and Ugolev, A. M. (1977). Comparative characterization of some brushborder enzymes isolated from the composition of membranes by detergents and proteases. (Russian). Doklady Akademii Nauk SSSR, 233, 487-490.

Koltushkina, G. G., and Ugolev, A. M. (1975). Membrane digestion and enzyme system of a microvillus. In Structure and Function of Biological Membranes. (Russian). pp. 276-306. Izdaniya Nauka: Moscow.

Louvard, D., Maroux, S., and Desnuelle, P. (1975). Topological studies on the hydrolases bound to the intestinal brush border membrane. II Interactions of free and bound aminopeptidase with a specific antibody. Biochimica et Biophysica Acta, 389, 389-400.

Louvard, D., Semeriva, M., and Maroux, S. (1976). The brush-border intestinal aminopeptidase, a transmembrane protein as probed by macromolecular photolabelling. Journal of Molecular Biology, 106, 1023-1035.

Maroux, S., and Louvard, D. (1976). On the hydrophobic part of aminopeptidase and maltases which bind the enzyme to the intestinal brush border membrane. Biochimica et Biophysica Acta, 419, 189-195.

Mityushova, N. M., and Ugolev, A. M. (1976). The regulatory properties of membrane enzymes of the middle intestine in some insects. (Russian). Doklady Akademii Nauk SSSR, 230, 992-994.

Pattus, F., Verger, R., and Desnuelle, P. (1976). Comparative study of the interactions of the trypsin and detergent form of the intestinal aminopeptidase with liposomes. Biochimica et Biophysica Research Communication, 69, 718-723.

Sigrist, H., Ronner, P., and Semenza, G. (1975). A hydrophobic form of the small intestinal sucrase-isomaltase complex. Biochimica et Biophysica, Acta 406, 433-446.

Ugolev, A. M. (1972). Membrane Digestion. (Russian). Izdaniya Nauka, Leningrad.

Ugolev, A. M., Gruzdkov, A. A., Egorova, V. V., Iezuitova, N. N., Koltushkina, G. G., Timofeeva, N. M. Tulyaganova, E. C., Tsvetkova, V. A., Chernyakhovskaya, M. Y., and Shcherbakov, G. G. (1974). Some characteristics of polysubstrate processes at the stage of membrane digestion and their importance in functioning of the digestive system. (Russian). Fiziologicheskii Zhurnal SSSR, 60, 240-250.

Ugolev, A. M., Gruzdkov, A. A., De Laey, P., Egorova, V. V., Iezuitova, N. N., Koltushkina, G. G., Timofeeva, N. M., Tulyaganova, E. C., Tsvetkova, V. A., Chernyakhovskaya, M. Y., and Shcherbakov, G. G. (1975a). Characterization of multisubstrate processes during membrane digestion. Nahrung, 19, 299-318.

Ugolev, A. M., Gruzdkov, A. A., De Laey, P., Egorova, V. V,. Iezuitova, N. N., Koltushkina, G. G., Timofeeva, N. M., Tulyaganova, E. C., Tsvetkova, V. A., Chernyakhovskaya, M. Y., and Shcherbakov, G. G. (1975b). Substrate interactions on the intestinal mucosa: a concept for the regulation of intestinal digestion. British Journal of Nutrition, 34, 205-220.

Ugolev, A. M., and Iezuitova, N. N. (1969). Determination of the activity of invertase and other disaccharidases. In Studies on the Digestive System in Man, pp. 192-196. Edited by A. M. Ugolev. (Russian). Izdaniya Nauka: Leningrad. 